\title{
Ramipril-based versus diuretic-based antihypertensive primary treatment in patients with pre-diabetes (ADaPT) study
}

\author{
Walter Zidek ${ }^{1 *}$, Joachim Schrader ${ }^{2}$, Stephan Lüders ${ }^{2}$, Stephan Matthaei ${ }^{3}$, Christoph Hasslacher $^{4}$, Joachim Hoyer ${ }^{5}$, \\ Claudia Zemmrich ${ }^{6}$, Peter Bramlage ${ }^{6}$, Claus-Dieter Sturm ${ }^{7}$ and W Dieter Paar ${ }^{8}$
}

\begin{abstract}
Background: Previous randomized controlled trials demonstrated a protective effect of renin angiotensin system blocking agents for the development of type-2 diabetes in patients with pre-diabetes. However, there are no realworld data available to illustrate the relevance for clinical practice.
\end{abstract}

Methods: Open, prospective, parallel group study comparing patients with an ACE inhibitor versus a diuretic based treatment. The principal aim was to document the first manifestation of type-2 diabetes in either group.

Results: A total of 2,011 patients were enrolled (mean age $69.1 \pm 10.3$ years; 51.6\% female). 1,507 patients were available for the per-protocol analysis (1,029 ramipril, 478 diuretic group). New-onset diabetes was less frequent in the ramipril than in the diuretic group over 4 years. Differences were statistically different at a median duration of 3 years (24.4\% vs 29.5\%; $p<0.05)$. Both treatments were equally effective in reducing BP (14.7 $\pm 18.0 / 8.5 \pm 8.2$ $\mathrm{mmHg}$ and $12.7 \pm 18.1 / 7.0 \pm 8.3 \mathrm{mmHg}$ ) at the 4 year follow-up ( $<0.001$ vs. baseline; $p=n$.s. between groups). In 38.6\% and $39.7 \%$ of patients BP was below 130/80 mmHg (median time-to-target 3 months). There was a significant reduction of cardiovascular morbidity and mortality in favour of ramipril $(p=0.033)$. No significant differences were found for a change in $\mathrm{HbA} 1 \mathrm{c}$ as well as for fasting blood glucose levels during follow-up. The rate of adverse events was higher in diuretic treated patients (SAE 15.4 vs. 12.4\%; $p<0.05$; AE 26.6 vs. 25.6\%; $p=$ n.s).

Conclusions: Ramipril treatment is preferable over diuretic based treatment regimens for the treatment of hypertension in pre-diabetic patients, because new-onset diabetes is delayed.

\section{Background}

About $20 \%$ of patients with hypertension will develop type 2 diabetes in a three year period [1] and hypertension is a frequent co-morbid condition in patients with pre-diabetes and the metabolic syndrome $[2,3]$. While patients with pre-diabetes have an increased risk of coronary heart disease or stroke already [4], there is a further substantial increase in cardiovascular risk when diabetes actually develops $[5,6]$ and the presence of hypertension multiplies this risk by a factor of three [7].

It was therefore important to recognize that diabetes development may be prevented by preferring blockers of

\footnotetext{
* Correspondence: walter.zidek@charite.de

'Medizinische Klinik IV, Charité - Universitätsmedizin Berlin, Campus Benjamin-Franklin, Berlin, Germany

Full list of author information is available at the end of the article
}

the renin angiotensin system (RAS) as opposed to older treatment options such as betablockers and diuretics which promoted its development [8]. Calcium channel blockers were neutral with this respect as shown in a supplemental analysis by Lam [9]. This was learned from a number of trials reporting significant reductions in the incidence of type 2 diabetes with renin-angiotensin blocking treatment strategies in comparison to placebo, diuretics or betablockers [1,10-17]. Most of these analyses were however post-hoc and endpoints not predefined or the development of diabetes not the primary endpoint. Trials with a pre-defined new-onset diabetes endpoint were ASCOT-BPLA [14,15], VALUE [16], DREAM [1] and, more recently, NAVIGATOR [17]. While there was a significant reduction of new onset diabetes in ASCOT-BLPA (HR 0.70; 95\%CI 0.63-0.78),

\section{C) Biomed Central}


VALUE (HR 0.77; 95\%CI 0.69-0.86) and NAVIGATOR (HR 0.86; 95\%CI 0.80-0.92), there was none in DREAM (HR 0.91 [95\%CI 0.80-1.03]).

Because there is no large scale study on the effectiveness of blocking the RAS for the prevention of diabetes in "real world" clinical practice [18-20] we designed the ACE inhibitor-based versus diuretic-based antihypertensive primary treatment in patients with prediabetes (ADaPT) study. We aimed to verify, that the perceived benefits of using a RAS based regimen over diuretics for the treatment of hypertension in patients with pre-diabetes are also seen in clinical practice. Patients were selected based on a high risk for the development of type 2 diabetes according to the modified PreDiSc Score [21].

\section{Methods}

\section{Design}

$\mathrm{ADaPT}$ is an open, prospective, non-randomised parallel group observation at 150 office based general physicians and internists. A detailed description of the design of the ADaPT investigation has been published previously [22]. The study complies with $\mathbb{S} 67(6)$ of the German Drug Law and was performed under the auspices of the German Hypertension League. Ethical approval was obtained by the institutional review board of the Charité, Berlin, Germany. Patients had to provide written informed consent prior to entering the study.

\section{Patient population}

Inclusion criteria for $\mathrm{ADaPT}$ were based on the PreDisc Score [21]: Age $\geq 45$ years (amended, original protocol $\geq 55$ years), systolic blood pressure $\geq 140$ and/or diastolic blood pressure $\geq 90 \mathrm{mmHg}$, fasting glucose (IFG) level $110-125 \mathrm{mg} / \mathrm{dl}$ in venous plasma or $100-109 \mathrm{mg} / \mathrm{dl}$ in capillary whole blood and an HbA1c of $6-6.5 \%$ within the last six months. Patients with higher blood glucose levels than mentioned above, with overt diabetes or antidiabetic drug treatment were excluded as well as patients with congestive heart failure, chronic renal insufficiency, history of myocardial infarction, stroke, drug or alcohol abuse or contraindications against any of the principal drugs applied. Patients in group 1 received ramipril either as monotherapy or in combination with felodipine or another calcium channel blocker, patients in group 2 any other diuretic with or without beta-blocker-based therapy without using renin angiotensin blocking agents. Assignment of patients to either group was at the discretion of the treating physician (non-randomized). In case of inadequate response a dose increase or addition of further combination drugs was allowed within the approved labelling and in accordance with the recommendations of the European Society of Hypertension [23].

\section{Endpoints}

The primary evaluation criterion of $\mathrm{ADaPT}$ was the first manifestation of type 2 diabetes (fasting glucose level $\geq$ $126 \mathrm{mg} / \mathrm{dl} / \geq 7.0 \mathrm{mmol} / \mathrm{l}$ ). Blood glucose related further criteria were the deterioration of pre-diabetes indicated by an increase of HbA1c of at least $10 \%$ over baseline, an increase of fasting glucose levels and a change of HbA1c. All laboratory values were analyzed in a central core laboratory. Blood pressure related criteria were achievement of a target $\mathrm{BP}<130 / 80 \mathrm{~mm} \mathrm{Hg}$ and the time needed to reach target. Major cardiovascular events and mortality as well as the type and frequency of adverse or serious adverse events (AE/SAE) were also recorded.

\section{Statistical analyses}

Data were obtained on a paper case report form and entered into a Microsoft Access 2003 database. Analyses were conducted with SPSS 17.0. Patients treated with ramipril (or ramipril-based combination therapies) and patients who received various a diuretic based treatment strategy (with the exception of ACEi or ARBs) were compared using descriptive statistics for continuous target data per treatment group and per total including the following: number of patients, means \pm standard deviation, or median. The absolute and relative frequencies in percentages were determined. For a comparison of the treatment groups with respect to the incidence of specific events (e.g. patients with first manifestation of diabetes mellitus type 2 or proportion of patients with deterioration of pre-diabetes), the chi-square or the log-rank tests was used.

\section{Results}

Between August 2004 and March 2006 a total of 2,108 patients were enrolled. Ninety-seven had to be excluded because of violations against the study protocol resulting in 2,011 patients available for the intention to treat analysis $-1,350$ patients were allocated to a ramipril based and 661 patients to a diuretic based therapy. The per-protocol analysis (1,507 patients) excluded all ramipril patients, who had received any diuretic or a beta-blocking agent and all patients of the diuretic group with concomitant ACEi or ARBs. In the ramipril group 15.3\% received calcium channel blocker and no patient in the diuretic group received a betablocker. Of these 1,394 patients were available for the 1 year follow-up, 1,286 for the 2 year, 1,040 patients for the 3 year and 483 for the 4 year follow-up.

\section{Patient characteristics}

Patients enrolled (ITT, 2,011 patients) had a mean age of $69.1 \pm 10.3$ years, and $51.6 \%$ were female. The mean BMI was $29.9 \pm 4.9 \mathrm{~kg} / \mathrm{m} 2$, which meant that $41.7 \%$ 
were obese. With the exception of a larger proportion of female patients in the diuretic group $(\mathrm{p}<0,001)$ all other characteristics, risk factors, laboratory values and co-medication were comparable in the two study groups (Table $1 \& 2$ ).

Office blood pressure at baseline was $147.4 \pm 15.9$ / $87.3 \pm 9.3 \mathrm{mmHg}$ in the ramipril group and $144.6 \pm$ $15.3 / 86.5 \pm 9.4 \mathrm{mmHg}$ in the diuretic group $(\mathrm{p}<0.001 /$ $\mathrm{p}=$ n.s.). Daytime ambulatory blood pressure was 138.2 $\pm 15.1 / 81.4 \pm 10.0$ with ramipril and $135.0 \pm 15.0 / 80.4 \pm$ 10.8 with diuretics $(\mathrm{p}=0.001 / \mathrm{p}=$ n.s.; Table 3$)$.

The mean fasting glucose at baseline was $94.4 \pm 21.3$ $\mathrm{mg} / \mathrm{dl}$ in the ramipril and $95.5 \pm 21.0 \mathrm{mg} / \mathrm{dl}$ in the diuretic group ( $\mathrm{p}=\mathrm{n}$.s.). HbA1c was $5.6 \pm 0.6 \%$ and 5.7 $\pm 0.7 \%$ respectively $(\mathrm{p}=\mathrm{n}$.s.). While none of the patients had diabetes at enrolment, $37.0 \%$ of ramipril treated and $40.4 \%$ of diuretic treated patients had a family history of diabetes $(\mathrm{p}=\mathrm{n} . \mathrm{s}$.$) .$
Patient characteristics of the per-protocol (PP) population were essentially identical to the ITT population (Tables 1, 2, 3). The only noteworthy differences were the lesser use of calcium channel blockers (0 vs. 13.8\%) in the diuretic group in the PP population.

\section{Primary endpoint}

The primary evaluation criterion was the first manifestation of type 2 diabetes defined as a fasting glucose level $\geq 126 \mathrm{mg} / \mathrm{dl} / \geq 7.0 \mathrm{mmol} / \mathrm{l}$. The prevalence of type- 2 diabetes was $0 \%$ at baseline (per exclusion criteria). Incidence rates were consistently higher in the diuretic than in the ramipril group through years 1 to 4. Strikingly however, incidence rates were 16.9 and $18.2 \%$ in the first year and between 2.5 and $7.6 \%$ in subsequent years 2 to 4 . The prevalence rose continuously during follow-up (Figure 1) reaching statistical significance at a median treatment duration of three

Table 1 Patient characteristics and co-morbidity at baseline

\begin{tabular}{|c|c|c|c|c|}
\hline & \multicolumn{2}{|c|}{ Intention to treat } & \multicolumn{2}{|c|}{ Per protocol } \\
\hline & $\begin{array}{l}\text { Ramipril } \\
(n=1,350)\end{array}$ & $\begin{array}{c}\text { Diuretic } \\
(n=661)\end{array}$ & $\begin{array}{c}\text { Ramipril } \\
(\mathrm{n}=1,029)\end{array}$ & $\begin{array}{c}\text { Diuretic } \\
(n=478)\end{array}$ \\
\hline Age (years $\pm S D$ ) & $69.4 \pm 10.4$ & $68.5 \pm 10.3$ & $69.4 \pm 10.5$ & $67.8 \pm 10.3$ \\
\hline Female (\%) & 48.7 & 57.5 & 48.5 & 58.4 \\
\hline $\mathrm{BMI}\left(\mathrm{kg} / \mathrm{m}^{2} \pm \mathrm{SD}\right)$ & $29.9 \pm 5.0$ & $29.8 \pm 4.8$ & $29.8 \pm 5.0$ & $29.7 \pm 4.9$ \\
\hline \multicolumn{5}{|l|}{ Risk factors* } \\
\hline Dyslipidemia (\%) & 56.4 & 56.6 & 54.7 & 56.9 \\
\hline Hyperuricemia (\%) & 21.7 & 23.0 & 20.5 & 20.5 \\
\hline CAD (\%) & 13.9 & 14.2 & 11.7 & 13.6 \\
\hline COPD (\%) & 6.7 & 4.8 & 6.8 & 5.4 \\
\hline Microalbuminuria (\%) & 6.2 & 5.4 & 6.2 & 5.6 \\
\hline Kidney disease (\%) & 3.0 & 2.9 & 2.8 & 2.1 \\
\hline Smoking (\%) & 15.6 & 14.4 & 15.6 & 14.4 \\
\hline \multicolumn{5}{|l|}{ Diabetes } \\
\hline Diabetes (\%) & 0 & 0 & 0 & 0 \\
\hline Family history (\%) & 37.0 & 40.4 & 37.2 & 41.4 \\
\hline \multicolumn{5}{|l|}{ Laboratory values } \\
\hline Total cholesterol (mg/dl \pm SD) & $222.4 \pm 43.4$ & $222.5 \pm 41.8$ & $223.4 \pm 42.0$ & $224.1 \pm 41.9$ \\
\hline HDL-cholesterol (mg/dl $\pm \mathrm{SD})$ & $61.7 \pm 16.0$ & $61.8 \pm 15.3$ & $62.5 \pm 16.1$ & $61.7 \pm 15.6$ \\
\hline LDL-cholesterol (mg/dl $\pm \mathrm{SD})$ & $128.6 \pm 35.6$ & $127.2 \pm 34.2$ & $129.3 \pm 35.4$ & $128.6 \pm 34.1$ \\
\hline Triglycerides (mg/dl \pm SD) & $169.1 \pm 168.3$ & $172.8 \pm 127.5$ & $161.8 \pm 97.8$ & $175.2 \pm 137.6$ \\
\hline $\begin{array}{l}\text { Fasting blood glucose } \\
(\mathrm{mg} / \mathrm{dl} \pm \mathrm{SD})\end{array}$ & $94.4 \pm 21.3$ & $95.5 \pm 21.0$ & $94.1 \pm 21.3$ & $95.7 \pm 21.5$ \\
\hline $\mathrm{HbA} 1 \mathrm{c}(\% \pm \mathrm{SD})$ & $5.6 \pm 0.6$ & $5.7 \pm 0.7$ & $5.6 \pm 0.6$ & $5.6 \pm 0.7$ \\
\hline Serum-creatinine $(\mathrm{mg} / \mathrm{dl} \pm \mathrm{SD})$ & $1.0 \pm 0.3$ & $1.0 \pm 0.3$ & $1.0 \pm 0.3$ & $1.0 \pm 0.3$ \\
\hline $\begin{array}{l}\text { Albuminuria } \\
\text { (mg/g creatinine } \pm \text { SD) }\end{array}$ & $33.1 \pm 121.6$ & $24.6 \pm 56.3$ & $33.8 \pm 131.4$ & $19.4 \pm 38.2$ \\
\hline Urinary creatinine $(\mathrm{mg} / \mathrm{dl} \pm \mathrm{SD})$ & $123.6 \pm 72.7$ & $122.7 \pm 74.0$ & $123.3 \pm 72.4$ & $120.6 \pm 71.6$ \\
\hline Cystatin-C (mg/dl $\pm \mathrm{SD})$ & $1.0 \pm 0.3$ & $1.0 \pm 0.3$ & $1.0 \pm 0.3$ & $1.0 \pm 0.3$ \\
\hline $\mathrm{hs}-\mathrm{CRP}(\mathrm{mg} / \mathrm{dl} \pm \mathrm{SD})$ & $5.2 \pm 8.7$ & $5.3 \pm 14.2$ & $5.1 \pm 8.5$ & $5.6 \pm 16.0$ \\
\hline
\end{tabular}

Legend. * available cases only (about $12 \%$ for microalbuminuria, about $1 \%$ for the other variables); SD, standard deviation; BMI, body mass index; CAD, coronary artery disease; COPD, chronic obstructive pulmonary disease; HDL, high density lipoprotein; LDL, low density lipoprotein; CRP, C-reactive protein 
Table 2 Antihypertensive treatment and co-medication at baseline

\begin{tabular}{|c|c|c|c|c|}
\hline & \multicolumn{2}{|c|}{ Intention to treat } & \multicolumn{2}{|c|}{ Per protocol } \\
\hline & $\begin{array}{c}\text { Ramipril } \\
(\mathrm{n}=1,350)\end{array}$ & $\begin{array}{c}\text { Diuretic } \\
(n=661)\end{array}$ & $\begin{array}{c}\text { Ramipril } \\
(\mathrm{n}=1,029)\end{array}$ & $\begin{array}{c}\text { Diuretic } \\
(\mathrm{n}=478)\end{array}$ \\
\hline \multicolumn{5}{|l|}{ Antihypertensive drugs } \\
\hline Ramipril (\%) & 76.2 & 0 & 100.0 & 0 \\
\hline CCB (\%) & 17.3 & 13.8 & 15.3 & 0 \\
\hline Diuretic (\%) & 0 & 72.3 & 0 & 100.0 \\
\hline Betablocker (\%) & 0.3 & 0 & 0 & 0 \\
\hline Central acting AH (\%) & 3.3 & 2.0 & 2.9 & 1.7 \\
\hline Alphablockers (\%) & 1.9 & 1.4 & 1.9 & 0.8 \\
\hline \multicolumn{5}{|l|}{ Co-Medication } \\
\hline Statins (\%) & 19.3 & 17.7 & 17.7 & 16.7 \\
\hline Anticoagulants (\%) & 3.2 & 5.4 & 2.8 & 5.0 \\
\hline Thienopyridines (\%) & 2.0 & 1.4 & 1.7 & 1.5 \\
\hline Aspirin (\%) & 21.7 & 20.4 & 20.5 & 18.4 \\
\hline
\end{tabular}

Legend. $\mathrm{CCB}$, calcium channel blocker; $\mathrm{AH}$, antihypertensives

years $(24.3 \%$ versus $29.0 \%, \Delta 4.7 \%$; $\mathrm{p}<0.05)$. The difference at 4 years was largely preserved $(\Delta 3.5 \%)$, but became non-significant.

\section{Secondary blood pressure - related endpoints}

Ramipril and diuretic based antihypertensive treatments were about equally effective in lowering blood pressure (Figure 2) using office blood pressure measurement. At a mean baseline blood pressure of $147.2 \pm 15.7 / 87.4 \pm$ $9.1 \mathrm{mmHg}$ in the ramipril and 144.6 $\pm 15.3 / 86.9 \pm 9.4$ $\mathrm{mmHg}$ in the diuretic group (Table 3) blood pressure was reduced by $14.7 \pm 18.0 / 8.5 \pm 8.2 \mathrm{mmHg}$ and $12.7 \pm$ $18.1 / 7.0 \pm 8.3 \mathrm{mmHg}$ at the 4 year follow-up $(\mathrm{p}<0.001$ vs. baseline; $\mathrm{p}=\mathrm{n} . \mathrm{s}$. between groups).

$79.8 \%$ of patients in the ramipril and $77.0 \%$ of patients in the diuretic group achieved a target blood pressure of $<140 / 90 \mathrm{mmHg}$ at the 4 year follow-up. In $38.6 \%$ and $39.7 \%$ of patients respectively blood pressure was below
130/80 mmHg. The median time to reach a target BP of 130/80 mmHg was 3 months in either group $(\mathrm{p}=$ n.s. $)$.

\section{Secondary glucose - related endpoints}

Laboratory assessments were performed every year. No data were available on the initiation of antidiabetic medication during follow-up.

Fasting glucose levels at baseline were about equal in both groups $(94.1 \mathrm{mg} / \mathrm{dl}$ in the ramipril group, $95.7 \mathrm{mg} / \mathrm{dl}$ in the diuretic group; $\mathrm{p}=\mathrm{n}$.s.). Values remained rather stable over the 4 year observational period; both within group comparisons showed a trend towards slightly lower values after year 4 in the ramipril group but were not significant (Figure 3, upper panel).

HbA1c values at baseline were $5.6 \pm 0.6$ in the ramipril and $5.6 \pm 0.7$ in the diuretic group $(\mathrm{p}=$ n.s. $)$ and remained virtually similar between groups throughout the 4 year observation. There was however a gradual

Table 3 Blood pressure at baseline

\begin{tabular}{|c|c|c|c|c|}
\hline & \multicolumn{2}{|c|}{ Intention to treat } & \multicolumn{2}{|c|}{ Per protocol } \\
\hline & Ramipril & Diuretic & Ramipril & Diuretic \\
\hline \multicolumn{5}{|l|}{ Office blood pressure } \\
\hline RR systolic (mmHg $\pm \mathrm{SD})$ & $147.4 \pm 15.9$ & $144.6 \pm 15.3$ & $147.2 \pm 15.7$ & $144.6 \pm 15.3$ \\
\hline RR diastolic (mmHg $\pm \mathrm{SD})$ & $87.3 \pm 9.3$ & $86.5 \pm 9.4$ & $87.4 \pm 9.1$ & $86.9 \pm 9.4$ \\
\hline $\mathrm{HR}(\mathrm{bpm} \pm \mathrm{SD})$ & $73.9 \pm 9.4$ & $73.0 \pm 9.8$ & $74.3 \pm 9.2$ & $73.5 \pm 9.8$ \\
\hline \multicolumn{5}{|l|}{ Daytime ABPM } \\
\hline RR systolic (mmHg \pm SD) & $138.2 \pm 15.1$ & $135.0 \pm 15.0$ & $138.7 \pm 15.3$ & $134.7 \pm 14.5$ \\
\hline $\mathrm{RR}$ diastolic $(\mathrm{mmHg} \pm \mathrm{SD})$ & $81.4 \pm 10.0$ & $80.4 \pm 10.8$ & $81.4 \pm 10.0$ & $80.3 \pm 10.4$ \\
\hline $\mathrm{HR}(\mathrm{bpm} \pm \mathrm{SD})$ & $76.3 \pm 10.5$ & $73.6 \pm 11.3$ & $76.4 \pm 10.4$ & $73.5 \pm 11.5$ \\
\hline \multicolumn{5}{|l|}{ Nighttime ABPM } \\
\hline RR systolic $(\mathrm{mmHg} \pm \mathrm{SD})$ & $126.7 \pm 17.2$ & $122.4 \pm 17.9$ & $126.6 \pm 17.3$ & $122.4 \pm 17.9$ \\
\hline $\mathrm{RR}$ diastolic (mmHg $\pm \mathrm{SD})$ & $72.4 \pm 11.2$ & $70.2 \pm 11.1$ & $72.1 \pm 11.2$ & $70.0 \pm 10.7$ \\
\hline $\mathrm{HR}(\mathrm{bpm} \pm \mathrm{SD})$ & $67.3 \pm 9.8$ & $66.1 \pm 9.9$ & $67.2 \pm 9.5$ & $65.9 \pm 9.9$ \\
\hline
\end{tabular}

Legend. RR, Riva Rocchi (blood pressure); HR, heart rate; SD, standard deviation; ABPM, ambulatory blood pressure monitoring 


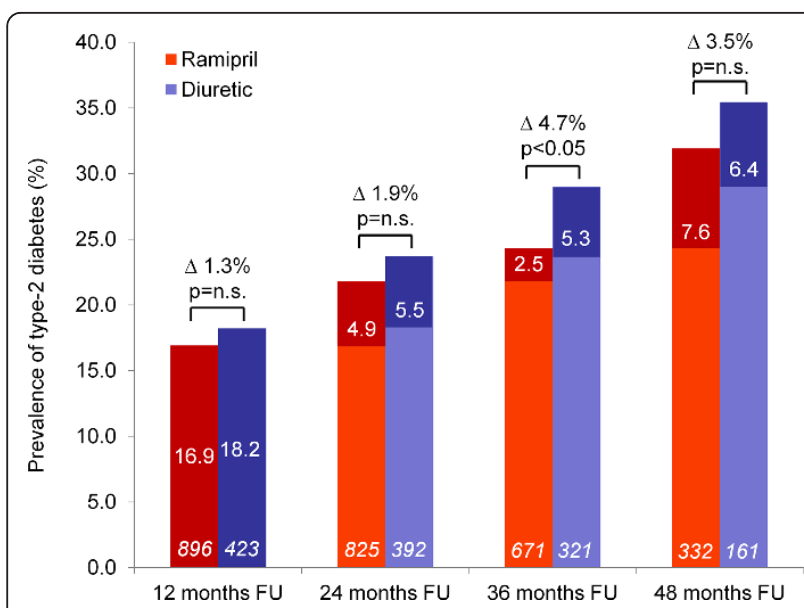

Figure 1 Prevalence of new-onset diabetes in patients during the 4 year follow-up. Legend: White numbers within columns indicate yearly incidence rates, patient numbers in italics; further differences between diabetes prevalence rates for each year are indicated together with the result of statistical testing.

deterioration in $0.1 \%$ steps per year, resulting in an HbA1c of $6.0 \pm 0.7 \%$ in both groups at 4 years (Figure 3 , lower panel). $34.9 \%$ of patients had an increase of > $10 \%$ of the HbA1c in the ramipril and $34.8 \%$ in the diuretic based group at year 4 . On the contrary $7.2 \%$ of patients had a decrease of $>10 \%$ of the HbAlc in the ramipril and $6.2 \%$ in the diuretic based group at year 4 . This mostly related to patients with a high HbA1c at baseline.

\section{Microalbuminuria}

Albuminuria levels at baseline were higher in the ramipril group compared to the diuretic group $(33.8 \pm 131.4$ vs. $19.4 \pm 38.2 \mathrm{mg} / \mathrm{dl} ; \mathrm{p}<0.01)$. After 4 years follow up

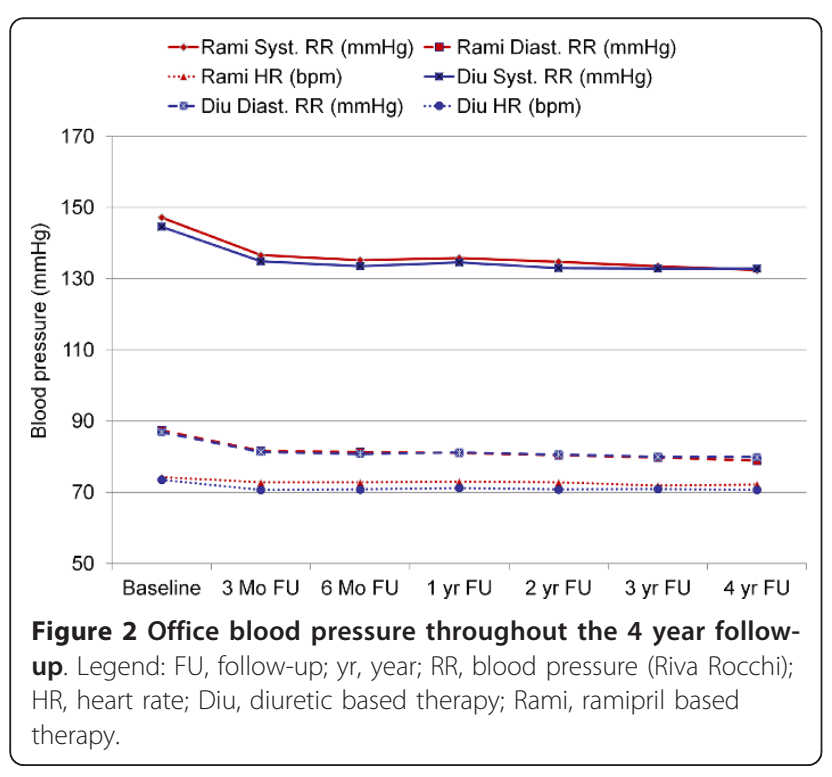

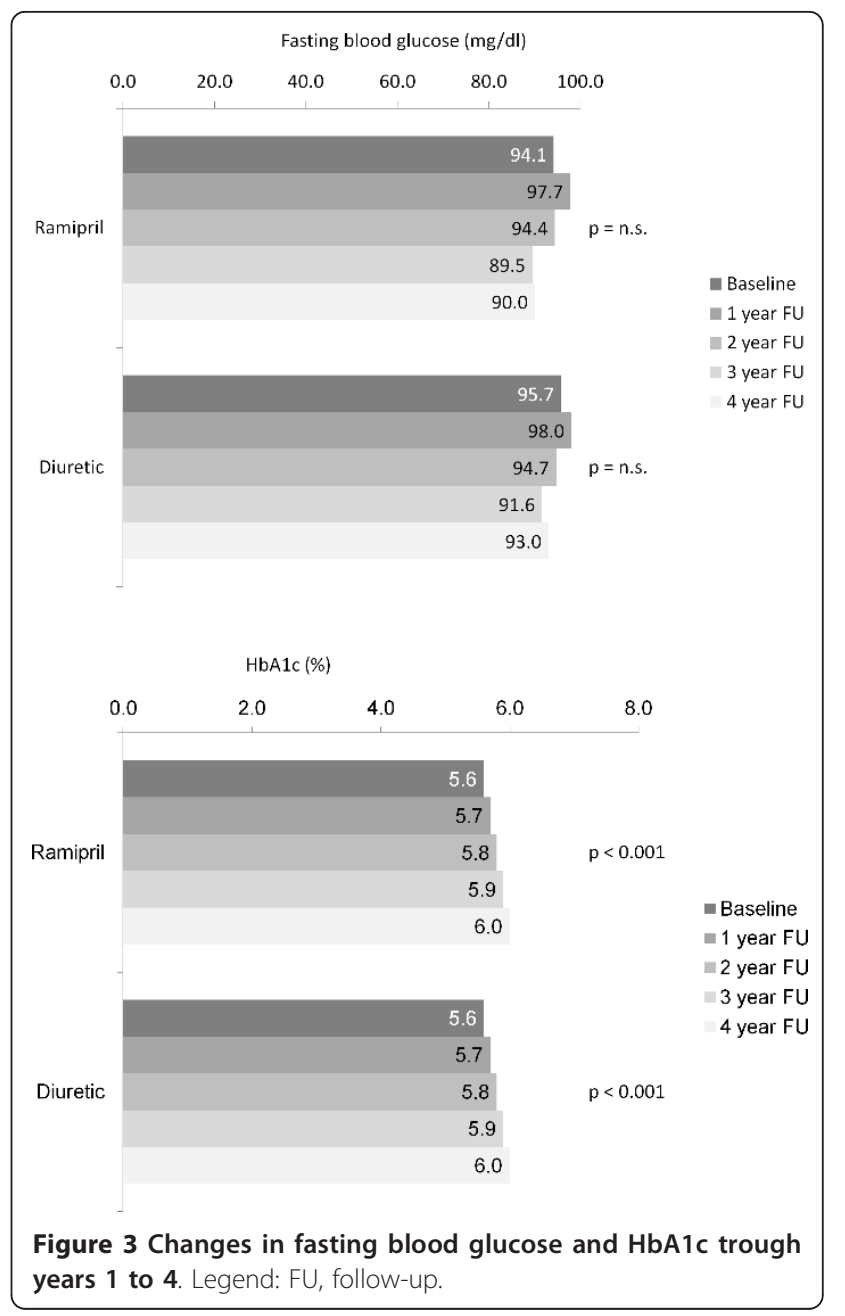

albuminuria was slightly reduced in the ramipril group $(23.6 \pm 67.0 \mathrm{mg} / \mathrm{dl} ; \mathrm{p}<0.05$ vs. baseline; $-30 \%)$, while it was increased in the diuretic group $(44.3 \pm 255.4 \mathrm{mg} / \mathrm{dl}$; $\mathrm{p}<0.01$ vs. baseline; $+128 \%$ ).

\section{Further secondary outcomes and adverse events}

The difference in total mortality ( $2.0 \%$ with ramipril vs. $2.9 \%$ with diuretics) as well as differences in major cardiovascular events $(3.7 \%$ with ramipril vs. $5.0 \%$ with diuretics) including first manifestation of symptomatic coronary heart disease, peripheral arterial occlusive disease and cerebrovascular events was similar in both treatment groups $(\mathrm{p}=\mathrm{n} . \mathrm{s}$.), while showing a trend for lower rates in the ramipril group. In a post hoc KaplanMeier analysis grouping both mortality and cardiovascular events, the difference between the ramipril and the diuretic treated group became significant in favour of ramipril $(\mathrm{p}=0.033)$ (Figure 4).

Serious adverse events ( 12.4 vs. $15.3 \%$; $=0.05)$ were more frequent in the diuretic based treatment group (all adverse events 25.6 vs. $26.6 \%$; $\mathrm{p}=$ n.s.). The most 


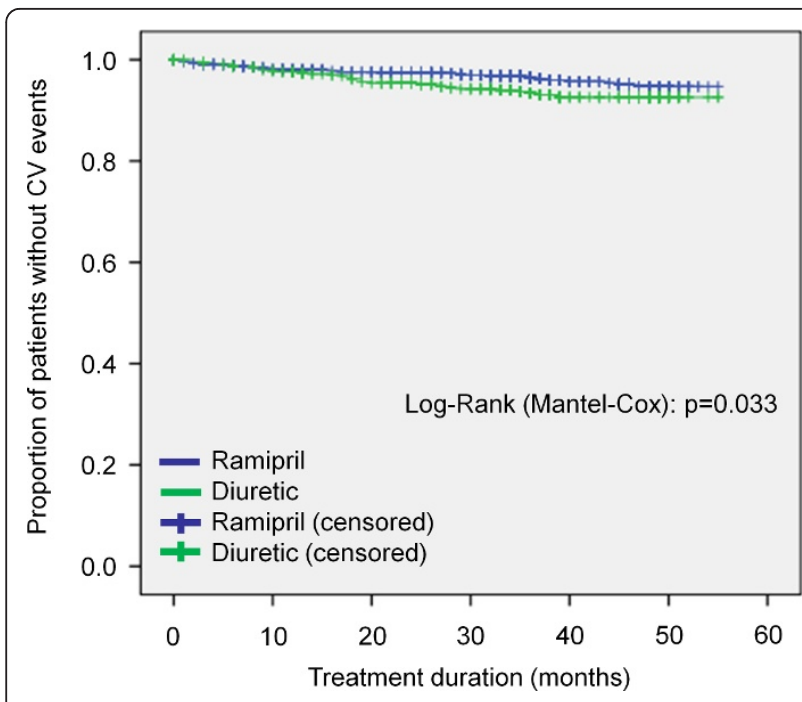

Figure 4 Freedom from cardiovascular events. Legend: CV, cardiovascular events and death.

frequent classification as per MedDRA system organ class (Table 4) for serious adverse events were cardiac disorders (24.4 vs. $25.7 \%$; $p=$ n.s.) followed by neoplasms (18.5 vs. $14.9 \% ; \mathrm{p}=$ n.s.), general disorders and administration site conditions ( 19.6 vs. $25.7 \%$; $\mathrm{p}=$ n.s. $)$ and nervous system disorders (14.9 vs. $28.7 \%$; $\mathrm{p}<0.05)$.

\section{Discussion}

Consistent with earlier studies $[1,24,25]$ we found a significant amount of patients developing overt diabetes within the 4 year study period. We also confirmed a significantly higher rate of new onset diabetes with a diuretic based antihypertensive treatment approach compared to ramipril based therapy at the three year follow-up. This finding was reflected by a continuous increase in HbA1c over the 4 years study period. Although our results are somewhat limited by the loss of significance for differences at 4 years, we are essentially able to confirm for a real-world setting the results of previous randomized, controlled trials, in which a reduction of newonset diabetes was reported for renin angiotensin blocking based treatment strategies in comparison to diuretics and/or betablockers in pre-diabetic, hypertensive or cardiovascular risk patients.

\section{New onset diabetes in perspective}

The results of $\mathrm{ADaPT}$ are in principal agreement with prior randomized trials using ACE inhibitors or angiotensin receptor blockers (Table 5). These have been summarized in several meta-analyses [8,24-29] of which the one by Al-Mallah [24] is the most comprehensive and the one by Tocci [25] the most recent which also included the NAVIGATOR trial [17]. The results of both meta-analyses were virtually identical although Al-Mallah also included results of trials with active comparators (diuretics, betablocker, calcium channel blockers) while Tocci only considered placebo controlled trials. Al-Mallah reported a relative risk of 0.78 (95\% CI $0.70-0.88)$ for the development of diabetes with ACE inhibitors and a relative risk of 0.8 (95\% CI $0.75-0.86)$ for angiotensin receptor blockers versus non-RAS based treatments [24].

Table 4 Number of patients with adverse event (AE) or serious adverse event (SAE) during survey

\begin{tabular}{|c|c|c|c|c|}
\hline \multirow[b]{2}{*}{ Type of adverse event } & \multicolumn{2}{|c|}{ Ramipril $(n=1,350)$} & \multicolumn{2}{|c|}{ Diuretic $(n=661)$} \\
\hline & n & $\%$ & $\mathrm{n}$ & $\%$ \\
\hline No AE & 962 & 71.3 & 463 & 70.0 \\
\hline Any AE & 388 & 28.7 & 198 & 30.0 \\
\hline Serious AE & 168 & 12.4 & 101 & 15.3 \\
\hline Not serious & 345 & 25.6 & 176 & 26.6 \\
\hline \multirow[t]{2}{*}{ MedDRA $^{(\mathbb{B}}$ primary System Organ Classes (SOC) V. 11.1 - (Serious) Adverse Events, $\mathrm{n}=2011$ (\%) } & \multicolumn{2}{|c|}{ Ramipril } & \multicolumn{2}{|c|}{ Diuretic } \\
\hline & $\mathrm{AE}$ & SAE & $\mathrm{AE}$ & SAE \\
\hline Musculosceletal and connective tissue disorders & 6.52 & 0.74 & 11.95 & 0.61 \\
\hline Infections and infestations & 6.22 & 0.37 & 9.98 & 0.45 \\
\hline Metabolism and nutrition disorders & 5.78 & 0.22 & 8.02 & 1.06 \\
\hline Respiratory, thoracic and mediastinal disorders & 5.93 & 0.22 & 3.03 & 0.45 \\
\hline Nervous system disorders & 3.41 & 1.70 & 6.66 & 3.78 \\
\hline Gastrointestinal disorders & 3.48 & 1.04 & 4.24 & 1.36 \\
\hline Cardiac disorders & 3.04 & 2.74 & 4.54 & 3.18 \\
\hline Vascular disorders & 3.26 & 1.48 & 2.57 & 1.36 \\
\hline General disorders and administration site conditions & 2.07 & 1.93 & 3.48 & 3.03 \\
\hline Injury, poisoning and procedural complications & 2.22 & 1.04 & 3.18 & 1.36 \\
\hline Surgical and medical procedures & 2.00 & 0.89 & 2.87 & 1.51 \\
\hline Neoplasms benign, malignant and unspecified (incl cysts and polyps) & 1.93 & 2.22 & 2.12 & 2.12 \\
\hline
\end{tabular}


Table 5 Results in perspective (adapted from [24])

\begin{tabular}{|c|c|c|c|c|c|}
\hline & RAS blocking agent & Control & Number of patients & Follow-up & $\mathrm{RR}(95 \% \mathrm{Cl})$ \\
\hline SOLVD [36] & Enalapril & Placebo & 4,228 & 3.4 & $0.26(0.13-0.53)$ \\
\hline AASK [30] & Ramipril & $\begin{array}{l}\text { Betablocker/ } \\
\text { Amlodipine }\end{array}$ & 1,094 & 4.1 & $0.64(0.45-0.90)$ \\
\hline HOPE [31] & Ramipril & Placebo & 9,297 & 5 & $0.67(0.52-0.85)$ \\
\hline ANBP2 $[37,38]$ & Enalapril & Diuretic & 6,083 & 4.1 & $0.70(0.56-0.86)$ \\
\hline ALLHAT [39] & Lisinopril & Chlorthalidone/Amlodipine & 33,357 & 4.9 & $0.75(0.59-0.94)$ \\
\hline IMAGINE [40] & Quinapril & Placebo & 2,553 & 2.95 & $0.79(0.48-1.29)$ \\
\hline ADaPT [22] & Ramipril & $\begin{array}{l}\text { Betablockers/ } \\
\text { Diuretic }\end{array}$ & 2,011 & 3 & $0.83(0.65-0.80)$ \\
\hline PEACE [41] & Trandolapril & Placebo & 8,290 & 4.8 & $0.85(0.74-0.97)$ \\
\hline CAPPP [42] & Captopril & $\begin{array}{c}\text { Betablockers/ } \\
\text { Diuretic }\end{array}$ & 10,985 & 6.1 & $0.89(0.78-1.03)$ \\
\hline DREAM $[1,32]$ & Ramipril & Placebo & 5,269 & 3 & $0.93(0.82-1.04)$ \\
\hline STOP-2 [43] & $\begin{array}{l}\text { Enalapril/ } \\
\text { Lisinopril }\end{array}$ & $\begin{array}{c}\text { Betablockers/ } \\
\text { Diuretic }\end{array}$ & 6,614 & 5 & $0.95(0.72-1.26)$ \\
\hline ALPINE [44] & Candesartan & $\mathrm{HCTZ}$ & 392 & 1 & $0.13(0.02-0.99)$ \\
\hline CASE-J [45] & Candesartan & Amlodipine & 4,703 & 3.2 & $0.65(0.44-0.98)$ \\
\hline LIFE [46] & Losartan & Atenolol & 9,193 & 4.8 & $0.75(0.64-0.88)$ \\
\hline CHARM [47] & Candesartan & Placebo & 7,599 & 3.2 & $0.81(0.66-0.99)$ \\
\hline SCOPE [48] & Candesartan & Placebo & 4,937 & 3.7 & $0.81(0.62-1.06)$ \\
\hline VALUE [16] & Valsartan & Amlodipine & 15,245 & 4.2 & $0.81(0.74-0.89)$ \\
\hline PRoFESS [49] & Telmisartan & Placebo & 20,332 & 2.5 & $0.83(0.65-1.04)$ \\
\hline TRANSCEND [50] & Telmisartan & Placebo & 5,926 & 4.6 & $0.86(0.72-1.02)$ \\
\hline NAVIGATOR [17] & Valsartan & Placeno & 9,306 & 5 & $0.86(0.80-0.92)$ \\
\hline
\end{tabular}

Legend. $\mathrm{RR}$, relative risk; $\mathrm{HCTZ}$, hydrochlorothiazide

In the analysis by Tocci both ACE inhibitors (OR 0.8; 95\%CI 0.7-1.0) and ARBs (OR 0.8; 95\%CI 0.8-0.9) reduced new-onset diabetes as compared to placebo [25]. These results are in agreement with the finding of an OR of 0.83 seen in $\mathrm{ADaPT}$.

There are two noteworthy findings in $\mathrm{ADaPT}$ that call for an appreciation. First the incidence rate for diabetes was about 3 times higher in the first year $(17.3 \%)$ as compared to subsequent years $(5.1 \%$ second, $3.4 \%$ third and $7.2 \%$ in the fourth year). This is in contrast with results of NAVIGATOR where incidence rates were about $9 \%$ each year and was not different across years 1 to 5 [17]. Further incidence rates were also low in the first year of DREAM and were progressively increasing through subsequent years [1]. Therefore the increased incidence rate in $\mathrm{ADaPT}$ during the first year is most likely artificial, possibly triggered by a closer surveillance of patients entering the observation. Another explanation might be the employed pre-selection of high risk patients by the PreDisc-Score in ADaPT. This might have distorted the natural time course of diabetes onset. Actually the overall diabetes incidence rate over 4 years was quite similar in ADaPT and NAVIGATOR/DREAM $[1,17]$. Second, while 3 year results were promising with respect to differences in incidence rates between ramipril and the diuretic group (24.4 vs. $29.5 \%, \Delta 4.7 \%$; $<<0.05$ ), 4 year results were nominally but not statistically different (31.9 vs. $35.4 \%, \Delta 3.5 \% ; \mathrm{p}=$ n.s.). This can be interpreted in two different directions: 1 ) The difference found at a median treatment duration of 3 years is "by chance" and the nonsignificant difference at months 12, 24 and 48 reflects the true effect of ramipril vs. diuretic based treatment on the incidence of diabetes. This is somewhat in line with the finding of a non-significant difference in fasting blood glucose levels in either group and the virtually identical trend for HbA1c which increased in parallel over time (p $<0.001)$. 2) On the contrary the 3 year result may also reflect the true effect of ramipril vs. diuretic based treatment. This is notion is supported by the nominally but statistically not different rate at year $4(\Delta 3.5 \%)$, which might be due the loss of $57.7 \%$ patients between year 3 and 4 which will limit the statistical power of this comparison. Further this interpretation is in line with the aforementioned meta-analyses [24,25] and 2 out of 3 trials reporting the effects of ramipril [1,30-32]. However, overall our study is small compared to other trials having reported outcomes with new-onset diabetes as an endpoint questioning that statistical power at year 4 is sufficient to actually capture differences between treatments.

The possibility for physicians in this real world trial to add a calcium channel blockers to the ramipril group and a betablocker to the diuretic group may be perceived to 
confound the principal comparison of this investigation and limit its interpretation. This is because betablockers have been demonstrated to adversely affect glucose control and calcium channel blockers, which were neutral with respect to the development of diabetes in a large network meta-analysis published by Elliott [8] and supplemented by Lam [9], have been reported to have a potentially beneficial effect on glucose tolerance and insulin sensitivity. Evidence was provided by a recent study in 17 non-diabetic patients with essential hypertension, where the third-generation calcium channel blocker azelnidipine proved to be more beneficial than second generation amlodipine [33]. While these results are of potential relevance for the interpretation of our findings, they may not fully apply: Only $15.3 \%$ of those receiving ramipril had a calcium channel blocker (mostly the second generation felodipine) added to their treatment. Moreover no patient in the diuretic group actually received an additional betablocker. On the other hand our findings may enforce the notion that a combination of an ACE inhibitor with a calcium channel blocker is actually beneficial with respect to the development of diabetes and diabetic complications as has been recently suggested by a trial comparing the combination of the third generation manidipine and delapril with delapril monotherapy or placebo [34]. In this trial, including exclusively hypertensive type-2 diabetic patients, combination treatment was able to ameliorate diabetic complications better than placebo (major cardiovascular events HR 0.17; 95\%CI 0.04-0.78).

Based on these considerations we are convinced that the effects of ramipril over a diuretic based antihypertensive treatment can also be observed in clinical practice. As pointed out by Al-Mallah the number of patients to prevent one case of new onset diabetes (50-100) is too small to justify their use for simple prevention [24]. However, the use of these medications to treat hypertensive and CHF patients at risk for diabetes can be recommended. Because angiotensin receptor recently went off-patent there is no future need to justify their use based on costeffectiveness considerations.

\section{Cardiovascular events and death}

Any cardiovascular events were reduced with ramipril vs. diuretic based treatment in our study ( $p=0.033)$. However, these results have to be considered with caution since they were determined from cases announced to the trialists as adverse or serious adverse events and serious underreporting of adverse events has been documented for observational studies [35]. Further a number of patients were lost to follow-up, introducing considerable uncertainty into these results. Further most of the other trials reporting incidence rates for diabetes failed to show a cardiovascular benefit. On the other hand the finding is in line with the most recent meta-analysis which included 11 trials and 84,363 patients which compared active treatment versus placebo [25]. Tocci et al found that active treatment using ACE inhibitors or angiotensin receptor blockers significantly reduced cardiovascular mortality (OR 0.9; 95\%CI 0.8-1.0; p < 0.01) and had a favorable impact on non-CV mortality (OR 0.7; 95\% CI $0.9-1.0 ; \mathrm{p}=0.2$ ) as compared to placebo [25]. The findings are further also in line with the results of HOPE comparing ramipril to placebo where treatment with ramipril reduced the rates of death from cardiovascular causes (relative risk 0.74; p < 0.001), myocardial infarction (RR 0.80; p < 0.001), stroke (RR 0.68; p < 0.001), death from any cause (RR 0.84; $\mathrm{p}=0.005)$, and complications related to diabetes ( 6.4 vs. $7.6 \%$; RR $0.84 ; \mathrm{p}=0.03$ ) [31]. Interestingly there was also a reduced event rate in cardiovascular high risk patients (OR 0.8; 95\%CI 0.7-0.9) observed in the meta-analysis by Tocci et al. [25].

\section{Pre-selection of high risk patients}

Given that 50 to 100 patients have to be treated with RAS blocking agents to prevent one case of new onset diabetes [24] might call for a pre-selection of patients. For this purpose the oral glucose tolerance test (OGTT) is useful but it is not convenient under daily practice conditions and the determination of fasting glucose or the HbA1c alone yields low sensitivity (62 and 58\% respectively) [21].

Therefore patients were selected for ADaPT based on the PreDisc-Score, that closely correlates to the outcome of an OGTT [21]. The PreDisc-Score has a sensitivity, specificity and positive and/or negative predictive value in the range of $80 \%$ [21]. However, compared to the original PreDiSc score, we had to adapt the score based on practical experiences in the initiation phase of the study: first, HbA1c was to be measured in a central laboratory instead of the originally planned local determination due to wide variation in locally determined values. Second, the age criterion was reduced to 45 years or older in order to accelerate the inclusion rate.

The utility of the PreDisc-Score in the present has to be considered on the background of a number of variables. 1) Non-interventional studies such as ADaPT are prone to unknown bias because they are non-randomized and non-blinded. A possible result is a blurred estimate of the true effect which might underestimate differences between treatment groups. To cope with this the PreDisc-Score appears appropriate to select a patient population at high risk. 2) Despite the selection of high risk patients incidence rates within 4 years are not different from trials such as NAVIGATOR/DREAM $[1,17]$, which might question this concept. Actually the adaption of the score to allow patients between 45 and 55 to enter the observation was never prospectively tested and has to be regarded as a limitation. 


\section{Limitations}

Limitations of our study are mainly the observational, not randomized character, which doesn't prevent bias through unknown impacting parameter. Yet the study goal was to confirm in a large cohort reflecting daily medical practice the findings of large existing randomized clinical trials. The only noteworthy differences in the baseline characteristics of both treatment groups seem to be a slightly higher proportion of male patients (51.4 vs. $42.6 \%$ ) and higher percentage of calcium channel blocker use in the ramipril group (18.6 vs. $15.3 \%$ ). We do not know if this affected the outcome in any relevant perspective, but such minor differences can never completely be ruled out in observational registries. As mentioned before a noteworthy limitation for interpretation of the presented outcome data is the fact, that the cardiovascular event and mortality analysis was only based on the AE/SAE reporting.

\section{Conclusions}

The present study documents a high incidence rate for type-2 diabetes during the course of a four year observational period. Our key finding is in line with the large prospective randomized studies such as ASCOT-BPLA, VALUE, DREAM and NAVIGATOR and meta-analyses, which reported a significantly reduced incidence of newonset diabetes with RAS based pharmacotherapy compared to diuretics, beta-blockers or placebo in pre-diabetic, hypertensive or cardiovascular risk patients. Patients at risk for the development of diabetes, who are identified with the PreDisc-Score should preferably be treated first line with ramipril rather than a diuretic or beta blocking agent for arterial hypertension.

\section{Conflict of interests}

WZ, JS, SL, SM, CH, JH, CZ and PB received consultancy fees, attended advisory boards and have held lectures for a number of pharmaceutical companies including Sanofi-Aventis. WDP declares to be and CZ to have been an employee of Sanofi-Aventis Germany. CDS has no conflict of interest to declare.

\footnotetext{
Acknowledgements

The ADaPT study is a project of the Germany Hypertension League. It is supported by an unrestricted educational grant by Sanofi-Aventis Germany, Berlin. Committee chair: Prof. Dr. W. Zidek, Berlin. Committee members: Prof. Dr. Schrader, Cloppenburg, Prof. Dr. Matthaei, Quakenbrück, Prof. Dr. Hasslacher, Heidelberg, Prof. Dr. Hoyer, Marburg, Prof. Dr. Paar, Berlin (without voting right).
}

\section{Author details}

${ }^{1}$ Medizinische Klinik IV, Charité - Universitätsmedizin Berlin, Campus Benjamin-Franklin, Berlin, Germany. ${ }^{2}$ St. Josephs Hospital, Krankenhausstr. 13, 49661 Cloppenburg, Germany. ${ }^{3}$ Diabetes Zentrum, Danziger Str. 2, 49610 Quakenbrück, Germany. ${ }^{4}$ Abteilung für Innere Medizin, St. Josefskrankenhaus, Landhausstr. 25, 69115 Heidelberg, Germany. ${ }^{5}$ Klinik für Innere Medizin, Nephrologie, Baldingerstr., 35033 Marburg, Germany. ${ }^{6}$ Institut für
Pharmakologie und präventive Medizin, Menzelstrasse 21, 15831 Mahlow, Germany. ${ }^{7}$ Tempestas - Institut für Medizinische Forschung, Krankenhausstr. 13, 49661 Cloppenburg, Germany. ${ }^{8}$ Medizinische Abteilung, Sanofi-Aventis Deutschland, Potsdamer Str.8, 10785 Berlin, Germany.

\section{Authors' contributions}

All authors made substantial contributions to conception and design, or acquisition of data, or analysis and interpretation of data. CZ and PB have drafted the manuscript. The other authors revised the manuscript for important intellectual content and all authors granted final approval of the manuscript to be published.

Received: 23 December 2011 Accepted: 9 January 2012

Published: 9 January 2012

\section{References}

1. Bosch J, Yusuf S, Gerstein HC, Pogue J, Sheridan P, Dagenais G, Diaz R, Avezum A, Lanas F, Probstfield J, Fodor G, Holman RR: Effect of ramipril on the incidence of diabetes. N Engl J Med 2006, 355(15):1551-1562.

2. Moebus S, Hanisch JU, Aidelsburger P, Bramlage P, Wasem J, Jöckel K-H: Impact of four different definitions used for assessment of the prevalence of metabolic syndrome in a primary health care setting. The German Metabolic and Cardiovascular Risk Project (GEMCAS). Cardiovasc Diabetol 2007, 6(1):22.

3. Lewington S, Clarke R, Qizilbash N, Peto R, Collins R: Age-specific relevance of usual blood pressure to vascular mortality: a meta-analysis of individual data for one million adults in 61 prospective studies. Lancet 2002, 360(9349):1903-1913.

4. Lipscomb ER, Finch EA, Brizendine E, Saha CK, Hays LM, Ackermann RT: Reduced 10-year risk of coronary heart disease in patients who participated in a community-based diabetes prevention program: the DEPLOY pilot study. Diabetes Care 2009, 32(3):394-396.

5. Pollare $\mathrm{T}$, Lithell $\mathrm{H}$, Berne $\mathrm{C}$ : Insulin resistance is a characteristic feature of primary hypertension independent of obesity. Metabolism 1990 39(2):167-174.

6. Economic costs of diabetes in the U.S. In 2007. Diabetes Care 2008, 31(3):596-615.

7. Verdecchia P, Reboldi G, Angeli F, Borgioni C, Gattobigio R, Filippucci L, Norgiolini S, Bracco C, Porcellati C: Adverse prognostic significance of new diabetes in treated hypertensive subjects. Hypertension 2004, 43(5):963-969.

8. Elliott WJ, Meyer PM: Incident diabetes in clinical trials of antihypertensive drugs: a network meta-analysis. Lancet 2007, 369(9557):201-207.

9. Lam SK, Owen A: Incident diabetes in clinical trials of antihypertensive drugs. Lancet 2007, 369(9572):1513-1514, author reply 1514-1515.

10. Kjeldsen SE, Julius S, Mancia G, McInnes GT, Hua T, Weber MA, Coca A, Ekman S, Girerd X, Jamerson K, Larochelle P, MacDonald TM, Schmieder RE, Schork MA, Stolt P, Viskoper R, Widimsky J, Zanchetti A: Effects of valsartan compared to amlodipine on preventing type 2 diabetes in high-risk hypertensive patients: the VALUE trial. J Hypertens 2006, 24(7):1405-1412.

11. Yusuf S, Gerstein H, Hoogwerf B, Pogue J, Bosch J, Wolffenbuttel BH, Zinman B: Ramipril and the development of diabetes. JAMA 2001, 286(15):1882-1885.

12. Yusuf $\mathrm{S}$, Ostergren JB, Gerstein HC, Pfeffer MA, Swedberg K, Granger CB, Olofsson B, Probstfield J, McMurray JV: Effects of candesartan on the development of a new diagnosis of diabetes mellitus in patients with heart failure. Circulation 2005, 112(1):48-53.

13. Califf RM, Boolell M, Haffner SM, Bethel MA, McMurray J, Duggal A, Holman RR: Prevention of diabetes and cardiovascular disease in patients with impaired glucose tolerance: rationale and design of the Nateglinide And Valsartan in Impaired Glucose Tolerance Outcomes Research (NAVIGATOR) Trial. Am Heart J 2008, 156(4):623-632.

14. Dahlof B, Sever PS, Poulter NR, Wedel H, Beevers DG, Caulfield M, Collins R, Kjeldsen SE, Kristinsson A, Mclnnes GT, Mehlsen J, Nieminen M, O'Brien E, Ostergren J: Prevention of cardiovascular events with an antihypertensive regimen of amlodipine adding perindopril as required versus atenolol adding bendroflumethiazide as required, in the AngloScandinavian Cardiac Outcomes Trial-Blood Pressure Lowering Arm (ASCOT-BPLA): a multicentre randomised controlled trial. Lancet 2005 366(9489):895-906 
15. Poulter NR, Wedel H, Dahlof B, Sever PS, Beevers DG, Caulfield M, Kjeldsen SE, Kristinsson A, Mclnnes GT, Mehlsen J, Nieminen M, O'Brien E, Ostergren J, Pocock S: Role of blood pressure and other variables in the differential cardiovascular event rates noted in the Anglo-Scandinavian Cardiac Outcomes Trial-Blood Pressure Lowering Arm (ASCOT-BPLA). Lancet 2005, 366(9489):907-913.

16. Julius S, Kjeldsen SE, Weber M, Brunner HR, Ekman S, Hansson L, Hua T, Laragh J, Mclnnes GT, Mitchell L, Plat F, Schork A, Smith B, Zanchetti A: Outcomes in hypertensive patients at high cardiovascular risk treated with regimens based on valsartan or amlodipine: the VALUE randomised trial. Lancet 2004, 363(9426):2022-2031.

17. McMurray, et al: Effect of valsartan on the incidence of diabetes and cardiovascular events. N Engl J Med 2010, 362(16):1477-1490.

18. Dusing $\mathrm{R}$, Lehnert $\mathrm{H}$ : Diabetogenic effect of antihypertensive treatment: primum nil nocere. Nephrol Dial Transplant 2004, 19(3):531-534

19. Frohlich ED: Treating hypertension - what are we to believe? N Engl J Med 2003, 348(7):639-641.

20. Whelton PK, Barzilay J, Cushman WC, Davis BR, liamathi E, Kostis JB, Leenen FHH, Louis GT, Margolis KL, Mathis DE, Moloo J, Nwachuku C, Panebianco D, Parish DC, Pressel S, Simmons DL, Thadani U, for the ACRG: Clinical Outcomes in Antihypertensive Treatment of Type 2 Diabetes, Impaired Fasting Glucose Concentration, and Normoglycemia: Antihypertensive and Lipid-Lowering Treatment to Prevent Heart Attack Trial (ALLHAT). Arch Intern Med 2005, 165(12):1401-1409.

21. Luders S, Hammersen F, Kulschewski A, Venneklaas U, Zuchner C, Gansz A, Schnieders M, Pfarr E, Sturm CD, Paar WD, Schrader J: Diagnosis of impaired glucose tolerance in hypertensive patients in daily clinical practice. Int J Clin Pract 2005, 59(6):632-638.

22. Zidek W, Schrader J, Luders S, Matthaei S, Hasslacher C, Hoyer J, Bramlage $P$, Sturm CD, Paar WD: First-line antihypertensive treatment in patients with pre-diabetes: rationale, design and baseline results of the ADaPT investigation. Cardiovasc Diabetol 2008, 7:22

23. Mancia G, et al: 2007 Guidelines for the Management of Arterial Hypertension: The Task Force for the Management of Arterial Hypertension of the European Society of Hypertension (ESH) and of the European Society of Cardiology (ESC). Journal of hypertension 2007, 25(6):1105-1187

24. Al-Mallah M, Khawaja O, Sinno M, Alzohaili O, Samra AB: Do angiotensin converting enzyme inhibitors or angiotensin receptor blockers prevent diabetes mellitus? A meta-analysis. Cardio/ J 2010, 17(5):448-456.

25. Tocci G, Paneni F, Palano F, Sciarretta S, Ferrucci A, Kurtz T, Mancia G, Volpe M: Angiotensin-Converting Enzyme Inhibitors, Angiotensin II Receptor Blockers and Diabetes: A Meta-Analysis of Placebo-Controlled Clinical Trials. Am J Hypertens 2011, 24(5):582-590.

26. Jandeleit-Dahm KA, Tikellis C, Reid CM, Johnston Cl, Cooper ME: Why blockade of the renin-angiotensin system reduces the incidence of newonset diabetes. J Hypertens 2005, 23(3):463-473.

27. Abuissa $\mathrm{H}$, Jones PG, Marso SP, O'Keefe JH Jr: Angiotensin-converting enzyme inhibitors or angiotensin receptor blockers for prevention of type 2 diabetes: a meta-analysis of randomized clinical trials. J Am Coll Cardiol 2005, 46(5):821-826

28. Gillies CL, Abrams KR, Lambert PC, Cooper NJ, Sutton AJ, Hsu RT, Khunti K Pharmacological and lifestyle interventions to prevent or delay type 2 diabetes in people with impaired glucose tolerance: systematic review and meta-analysis. BMJ 2007, 334(7588):299.

29. Geng DF, Jin DM, Wu W, Xu Y, Wang JF: Angiotensin receptor blockers for prevention of new-onset type 2 diabetes: A meta-analysis of 59,862 patients. Int J Cardiol 2010

30. Norris K, Bourgoigne J, Gassman J, Hebert L, Middleton J, Phillips RA, Randall O, Rostand S, Sherer S, Toto RD, Wright JT, Wang X, Greene T, Appel $L$, Lewis J: Cardiovascular outcomes in the African American Study of Kidney Disease and Hypertension (AASK) Trial. Am J Kidney Dis 2006, 48(5):739-751.

31. Yusuf S, Sleight P, Pogue J, Bosch J, Davies R, Dagenais G: Effects of an angiotensin-converting-enzyme inhibitor, ramipril, on cardiovascular events in high-risk patients. The Heart Outcomes Prevention Evaluation Study Investigators. N Engl J Med 2000, 342(3):145-153.

32. Gerstein HC, Yusuf S, Holman R, Bosch J, Pogue J: Rationale, design and recruitment characteristics of a large, simple international trial of diabetes prevention: the DREAM trial. Diabetologia 2004, 47(9):1519-1527.
33. Fukao K, Shimada K, Hiki M, Kiyanagi T, Hirose K, Kume A, Ohsaka H, Matsumori R, Kurata T, Miyazaki T, Daida H: Effects of calcium channel blockers on glucose tolerance, inflammatory state, and circulating progenitor cells in non-diabetic patients with essential hypertension: a comparative study between Azelnidipine and amlodipine on glucose tolerance and endothelial function - a crossover trial (AGENT). Cardiovasc Diabetol 2011, 10:79.

34. Ruggenenti P, Lauria G, lliev IP, Fassi A, llieva AP, Rota S, Chiurchiu C, Barlovic DP, Sghirlanzoni A, Lombardi R, Penza P, Cavaletti G, Piatti ML, Frigeni B, Filipponi M, Rubis N, Noris G, Motterlini N, Ene-lordache B, Gaspari F, Perna A, Zaletel J, Bossi A, Dodesini AR, Trevisan R, Remuzzi G: Effects of manidipine and delapril in hypertensive patients with type 2 diabetes mellitus: the delapril and manidipine for nephroprotection in diabetes (DEMAND) randomized clinical trial. Hypertension 2011, 58(5):776-783

35. Martin RM, Kapoor KV, Wilton LV, Mann RD: Underreporting of suspected adverse drug reactions to newly marketed ("black triangle") drugs in general practice: observational study. BMJ 1998, 317(7151):119-120.

36. Vermes E, Ducharme A, Bourassa MG, Lessard M, White M, Tardif JC: Enalapril reduces the incidence of diabetes in patients with chronic heart failure: insight from the Studies Of Left Ventricular Dysfunction (SOLVD). Circulation 2003, 107(9):1291-1296.

37. Nelson MR, Reid CM, Ryan P, Willson K, Yelland L: Self-reported adherence with medication and cardiovascular disease outcomes in the Second Australian National Blood Pressure Study (ANBP2). Med J Aust 2006, 185(9):487-489.

38. Wing LM, Reid CM, Ryan P, Beilin LJ, Brown MA, Jennings GL, Johnston Cl, McNeil JJ, Macdonald GJ, Marley JE, Morgan TO, West MJ: A comparison of outcomes with angiotensin-converting-enzyme inhibitors and diuretics for hypertension in the elderly. N Engl J Med 2003, 348(7):583-592.

39. ALLHAT Collaborative Research Group: Major outcomes in high-risk hypertensive patients randomized to angiotensin-converting enzyme inhibitor or calcium channel blocker vs diuretic: The Antihypertensive and Lipid-Lowering Treatment to Prevent Heart Attack Trial (ALLHAT). JAMA 2002, 288(23):2981-2997.

40. Rouleau JL, Warnica WJ, Baillot R, Block PJ, Chocron S, Johnstone D, Myers MG, Calciu CD, Dalle-Ave S, Martineau P, Mormont C, van Gilst WH: Effects of angiotensin-converting enzyme inhibition in low-risk patients early after coronary artery bypass surgery. Circulation 2008, 117(1):24-31.

41. Braunwald E, Domanski MJ, Fowler SE, Geller NL, Gersh BJ, Hsia J, Pfeffer MA, Rice MM, Rosenberg YD, Rouleau JL: Angiotensin-convertingenzyme inhibition in stable coronary artery disease. N Engl J Med 2004, 351(20):2058-2068

42. Hansson L, Lindholm LH, Niskanen L, Lanke J, Hedner T, Niklason A, Luomanmaki K, Dahlof B, de Faire U, Morlin C, Karlberg BE, Wester PO, Bjorck JE: Effect of angiotensin-converting-enzyme inhibition compared with conventional therapy on cardiovascular morbidity and mortality in hypertension: the Captopril Prevention Project (CAPPP) randomised trial. Lancet 1999, 353(9153):611-616.

43. Hansson L: Results of the STOP-Hypertension-2 trial. Blood Press Supp/ 2000, 2:17-20.

44. Lindholm LH, Persson M, Alaupovic P, Carlberg B, Svensson A Samuelsson O: Metabolic outcome during 1 year in newly detected hypertensives: results of the Antihypertensive Treatment and Lipid Profile in a North of Sweden Efficacy Evaluation (ALPINE study). $J$ Hypertens 2003, 21(8):1563-1574.

45. Ogihara T, Nakao K, Fukui T, Fukiyama K, Ueshima K, Oba K, Sato T, Saruta T: Effects of candesartan compared with amlodipine in hypertensive patients with high cardiovascular risks: candesartan antihypertensive survival evaluation in Japan trial. Hypertension 2008, 51(2):393-398.

46. Dahlof B, Devereux RB, Kjeldsen SE, Julius S, Beevers G, Faire U, Fyhrquist F, Ibsen H, Kristiansson K, Lederballe-Pedersen O, Lindholm LH, Nieminen MS, Omvik P, Oparil S, Wedel H: Cardiovascular morbidity and mortality in the Losartan Intervention For Endpoint reduction in hypertension study (LIFE): a randomised trial against atenolol. Lancet 2002, 359(9311):995-1003.

47. Pfeffer MA, Swedberg K, Granger CB, Held P, McMurray JJ, Michelson EL, Olofsson B, Ostergren J, Yusuf S, Pocock S: Effects of candesartan on mortality and morbidity in patients with chronic heart failure: the CHARM-Overall programme. Lancet 2003, 362(9386):759-766. 
48. Lithell H, Hansson L, Skoog I, Elmfeldt D, Hofman A, Olofsson B,

Trenkwalder P, Zanchetti A: The Study on Cognition and Prognosis in the Elderly (SCOPE): principal results of a randomized double-blind intervention trial. J Hypertens 2003, 21(5):875-886.

49. Yusuf $\mathrm{S}$, et al: Telmisartan to prevent recurrent stroke and cardiovascular events. N Engl J Med 2008, 359(12):1225-1237.

50. Yusuf S, Teo K, Anderson C, Pogue J, Dyal L, Copland I, Schumacher H, Dagenais $G$, Sleight P: Effects of the angiotensin-receptor blocker telmisartan on cardiovascular events in high-risk patients intolerant to angiotensin-converting enzyme inhibitors: a randomised controlled trial. Lancet 2008, 372(9644):1174-1183.

doi:10.1186/1475-2840-11-1

Cite this article as: Zidek et al:: Ramipril-based versus diuretic-based antihypertensive primary treatment in patients with pre-diabetes (ADaPT) study. Cardiovascular Diabetology 2012 11:1.

\section{Submit your next manuscript to BioMed Central} and take full advantage of:

- Convenient online submission

- Thorough peer review

- No space constraints or color figure charges

- Immediate publication on acceptance

- Inclusion in PubMed, CAS, Scopus and Google Scholar

- Research which is freely available for redistribution

Submit your manuscript at www.biomedcentral.com/submit
C Biomed Central 